\title{
Chlorophyll and photosynthetic efficiency of size-fractionated sea-ice microalgae (Hudson Bay, Canadian Arctic)*
}

\author{
L. Legendre ${ }^{1}$, S. Demers ${ }^{2}$, M. Gosselin ${ }^{1}$ \\ 1 Département de biologie, Université Laval, Québec, Québec G1K 7P4, Canada \\ ${ }^{2}$ Institut Maurice-Lamontagne, Ministère des Pêches et des Océans, 850 route de la Mer, Mont-Joli, Québec G5H $3 Z 4$, Canada
}

\begin{abstract}
Microalgal samples collected at the ice-water interface (Hudson Bay, Canadian Arctic) were size fractionated in order to determine if small algae, corresponding to the size of picoplankton in open waters, were present in the seaice environment. The $<5 \mu \mathrm{m}$ fraction was found to account for up to $4 \%$ of total chlorophyll a and $20 \%$ of total chlorophyll $c$. Photosynthetically active algae were present in the $<1 \mu \mathrm{m}$ fraction. Their photosynthetic efficiency was lower than that of the large ice diatoms, which indicated better adaptation of these larger cells to low under-ice light intensities. This is contrary to what has generally been observed for picoplankton in open waters. The ecological significance of ice picoalgae remains to be assessed.
\end{abstract}

Phytoplankton in oceanic waters are dominated by small cells less than a few $\mu \mathrm{m}$ in diameter designated as picoplankton $(0.2$ to $2.0 \mu \mathrm{m}$ : Sieburth et al. 1978) or ultraplankton $(<5$ to $10 \mu \mathrm{m}$ : Sverdrup et al. 1942). Picoplankton consist of phycoerythrin-rich cyanobacteria and minute eucaryotic algae (see the reviews by Carr \& Wyman 1986 and Thomsen 1986). In oceanic waters, they typically account for more than $50 \%$ of the chlorophyll a (e.g. Berman 1975, Herbland \& Le Bouteiller 1981, Platt et al. 1983, Takahashi \& Bienfang 1983, Takahashi \& Hori 1984, Takahashi et al. 1985, Putt \& Prézelin 1985, Glover et al. 1986a). Given their high photosynthetic biomass, picoplankton also account for a large proportion of the primary production. They are typically responsible for about 50 to $60 \%$ of total primary production in oceanic oligotrophic waters (Paerl 1977. Herbland \& Le Bouteiller 1981, Li et al. 1983, Platt et al. 1983), and proportions higher than $75 \%$ have been reported in shelf waters by Berman (1975), Takahashi \& Bienfang (1983), Putt \& Prézelin (1985), Glover et al. (1986a) and Prézelin et al. (1986). Lower pro-

\footnotetext{
- Contribution to the programs of GIROQ (Groupe interuniversitaire de recherches océanographiques du Québec) and of the Maurice-Lamontagne Institute, Canada
}

portions (20 to $30 \%$ ) have been found in the Celtic Sea by Joint \& Pomroy (1983) and Joint et al. (1986). In addition, picoplankton have higher photosynthetic efficiency (photosynthesis per unit photon fluence rate) at low irradiance than larger cells, which could enhance their contribution to primary production, at least at depth. This was shown for both laboratory cultures and natural populations (e.g. Glover \& Morris 1981, Morris \& Glover 1981, Platt et al. 1983, Barlow \& Alberte 1985, Glover et al. 1985, 1986a, b, Putt \& Prézelin 1985, Joint $\&$ Pomroy 1986). In the chlorophyll maximum for example, photosynthetic efficiency per unit chlorophyll a $\left(\alpha^{\mathrm{B}}\right)$ was higher for picoplankton than for larger cells by a factor of 1.5 in California coastal waters (Putt \& Prezélin 1985) and by a factor of 2 in the North Atlantic Ocean (Platt et al. 1983). In the surface mixed layer of the Celtic Sea, Joint \& Pomroy (1986) reported $\alpha^{\mathrm{B}}$ values with a factor of $\approx 3$ between the $<1 \mu \mathrm{m}$ and the $>5 \mu \mathrm{m}$ fractions.

In the North Atlantic Ocean, Murphy \& Haugen (1985) found a latitudinal gradient in the taxonomic composition of picoplankton; from $36.51^{\circ}$ to $61.35^{\circ} \mathrm{N}$, cyanobacteria decreased by a factor of 10 to 100 while eucaryotic cells increased 5-fold. This gradient correlated, at least in part, with decreasing temperature, but other factors such as light and nutrients may have been involved as well. In the Antarctic Ocean, Probyn \& Painting (1985) observed high proportions of particulate organic carbon (up to $94 \%$ ) and nitrogen (up to $60 \%$ ) in the $<1 \mu \mathrm{m}$ fraction near the ice edge. It is therefore expected that very small algal cells should be present in polar waters.

In polar seas, ice microalgae constitute an important component of the primary biomass and production (e.g. Subba Rao \& Platt 1984, Horner 1985a, Demers et al. 1986). In addition, bacteria are both present and active in the sea ice (see the review of Sullivan 1985). Given 
the possible presence of picoplanktonic cells in polar waters and the actual occurrence of bacteria in the sea ice, it was hypothesized that very small organisms should be found among the ice microalgae. In order to test this hypothesis, ice algae were size-fractionated for measurements of chlorophyll and photosynthetic carbon uptake.

Sampling was conducted during April and May 1985 at a field station located on firstyear ice $27 \mathrm{~km}$ off Kuujjuarapik $\left(55^{\circ} 30.1 \mathrm{~N}, 77^{\circ} 44.5 \mathrm{~W}\right)$, Hudson Bay, Canadian Arctic. Microalgae were collected at the icewater interface by SCUBA divers using a 2.01 syringe sampler (slurp gun). Details of sampling procedures are given in Barlow et al. (in press). On 3 different occasions, 6 subsamples (125 $\mathrm{ml}$ on $29 \mathrm{Apr} ; 60 \mathrm{ml}$ on 3 and 7 May) were inoculated with $10 \mu \mathrm{Ci} \mathrm{H}^{14} \mathrm{CO}_{3}$ and put in a Hawaiian-type incubator (Doty \& Oguri 1959), in which under-ice water was continuously circulated in order to keep the temperature close to natural conditions. Incubations were under $43,17,11,8,1$ and $0 \mu$ Einst $\mathrm{m}^{-2} \mathrm{~s}^{-1}$ of blue-green light that approximated the colour of the under-ice illumination (Rochet et al. 1986); bags of black tulle were used to obtain the various light intensities, and the dark bottles were wrapped in aluminum foil. After $4 \mathrm{~h}$ incubations, samples were sequentially filtered onto 5.0, 1.0 and $0.8 \mu \mathrm{m}$ Nuclepore filters. Filters were put into scintillation vials with $0.2 \mathrm{ml} \mathrm{HCl} 0.5 \mathrm{~N}$ (Lean \& Burnison 1979), and $10 \mathrm{ml}$ Aquasol added before counting the samples by liquid scintillation (Pugh 1973). Simultaneously, and also on $23 \mathrm{Apr}, 50 \mathrm{ml}$ subsamples were size-fractionated for chlorophyll analyses. Duplicate subsamples were sequentially filtered onto Nuclepore $5.0 \mu \mathrm{m}$ and Whatman GF/F filters, and also onto Nuclepore $1.0 \mu \mathrm{m}$ and GF/F filters; this resulted in 4 fractions $1>5.0$, $<5.0,>1.0$ and $<1.0 \mu \mathrm{m}$ ). Four subsamples were also directly filtered onto $\mathrm{GF} / \mathrm{F}$, the filtrate of 2 of them being filtered onto $0.2 \mu \mathrm{m}$ Nuclepore to determine if chlorophyll-containing particles passed through the GF/F filters. Pigments were extracted in $90 \%$ acetone during $\approx 24 \mathrm{~h}$ in the dark, and absorbances measured with a spectrophotometer according to Strickland \& Parsons (1972). Concentrations of the various chlorophylls were calculated using the equations of Jeffrey \& Humphrey (1975).

The 3 size fractions for photosynthetic activities $(>5.0,5.0$ to 1.0 and $<1.0 \mu \mathrm{m})$ did not directly correspond to the 4 chlorophyll fractions. In order to make the 2 sets of measurement correspond, size-fractionated activities were combined as follows: $>5 \mu \mathrm{m}_{\mathrm{i}}<5.0 \mu \mathrm{m}$ $=(5.0 \text { to } 1.0+<1.0 \mu \mathrm{m})_{i}>1.0 \mu \mathrm{m}=(>5.0+5.0$ to $1.0 \mu \mathrm{m})$; and $<1.0 \mu \mathrm{m}$. Combining the fractions could also reduce the effects of possible inaccuracies resulting from sequential filtering. Rochet et al. (1986) found that $I_{m}$ of ice algae incubated under blue-green light was $>40$. Einst $\mathrm{m}^{-2} \mathrm{~s}^{-1}$ during the whole sampling season, which indicates that maximum photon fluence rate in the incubator ( $43 \mu$ Einst $\mathrm{m}^{-2} \mathrm{~s}^{-1}$ ) was not high enough to achieve saturation. Consequently, the initial slope (photosynthetic efficiency; $\alpha^{\mathrm{B}}$ ) was the only parameter estimated for the photosynthesis versus irradiance curves. This was done by linear regression of photosynthetic activities, normalized per unit chlorophyll (B: biomass), on photon fluence rates.

Potential errors resulting from size fractionation have been reviewed by $\mathrm{Li}$ (1986). He concluded that there is no general rule for cell retention on filters, since it depends not only on pore size and vacuum pressure but also on differences in species, clones and physiology. For example, high pressure may force the passage of cells through the upper bound filter, but it may also reduce the number of cells in the filtrate as a consequence of particle impaction on the filter and cell rupture. It cannot therefore be excluded that the true importance of the smaller cells be underestimated in the $<5.0$ and $<1.0 \mu \mathrm{m}$ fractions. On the other hand, fragments of eukaryotic cells may be caught on the small pore filter during ${ }^{14} \mathrm{C}$ experiments, and incorrectly attributed to carbon fixed by picoplankton (Waterbury et al. 1986). However, given the low specific activities in the small-sized fractions (Table 2), it is unlikely that this occurred in the present study.

The proportion of pigments passing through Whatman GF/F filters (and retained on $0.2 \mu \mathrm{m}$ Nuclepore filters) was on the average less than $5 \%$, which indicates good efficiency of the GF/F filters. Chlorophyll analyses provided 8 independent estimates of pigments retained on GF/F filters; these are the duplicate fractionations $(>5.0+<5.0 \mu \mathrm{m})$ and $(>1.0+<1.0 \mu \mathrm{m})$, and the $4 \mathrm{GF} / \mathrm{F}$ filtrations. Chlorophyll $b$ was almost always below detection, and values for chlorophylls a and $c$ were close enough to provide good estimates of the means (Fig. 1). Ratios of chlorophyll a to chlorophyll $c$ (5.1 to 8.0) were lower than those (15.0 to 24.4) reported by Barlow et al. (in press) for corresponding subsamples analysed by high performance liquid chromatography using the method of Mantoura \& Llewellyn (1983). This is because the standard spectrophotometric technique yielded higher estimates of chlorophyll $c$ than HPLC analysis.

Table 1 gives the relative proportions in both chlorophyll a and chlorophyll $c$ in the $<5$ and $<1 \mu \mathrm{m}$ size fractions. These indicate that very small cells were indeed present in the sea-ice microflora, and that they were richer in chlorophyll $c$ relative to chlorophyll a than the larger cells. Such microalgae cannot be called picoplankton, since ice algae are not planktonic but rather grow in close association with sea ice. Unlike picoplankton in oceanic waters, picoalgae at the icewater interface accounted for only a small proportion of 


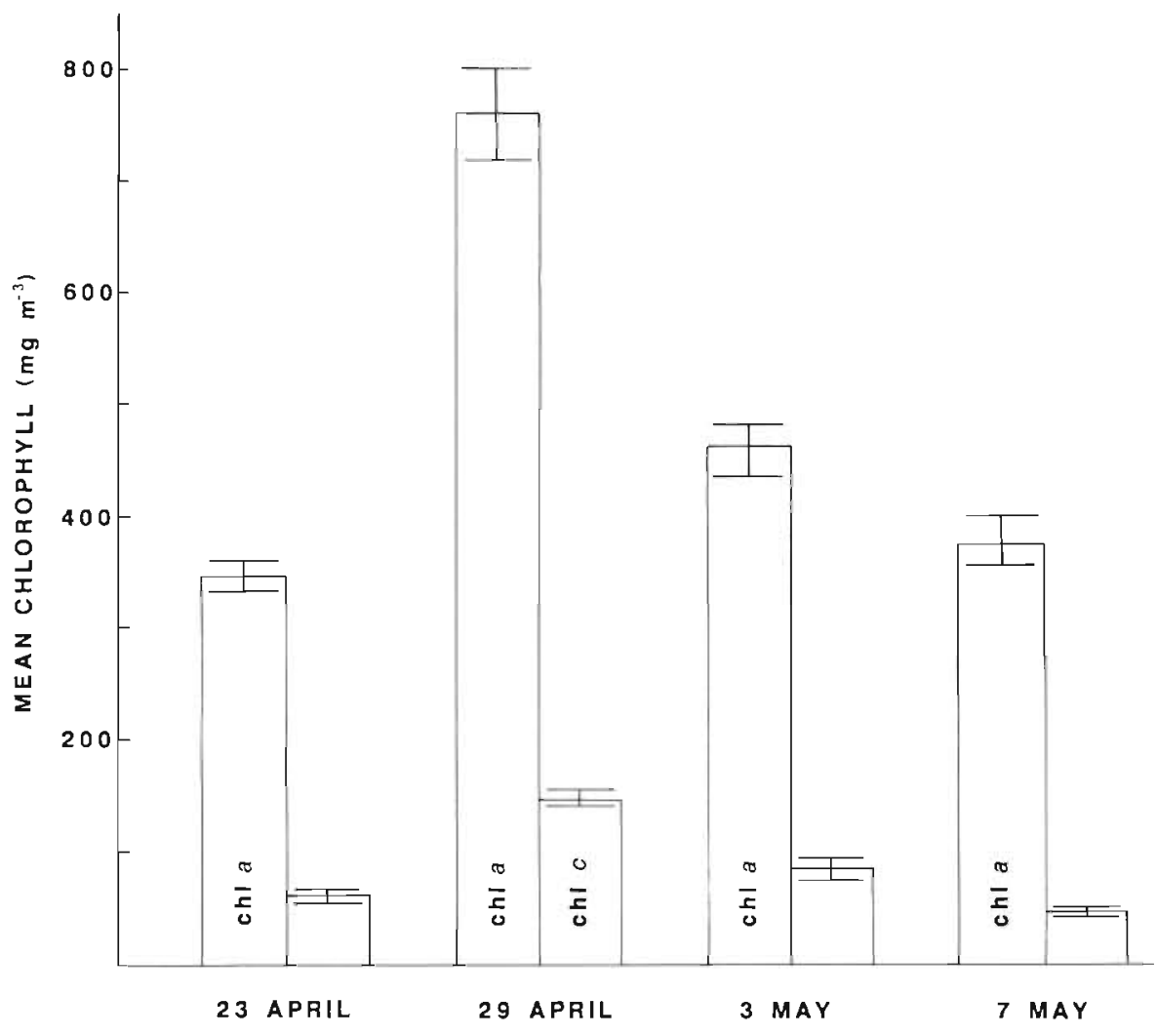

Fig. 1. Mean values for chlorophyll $a$ and $c$ in samples collected at the ice-water interface; $5 \%$ confidence intervals are drawn
Table 1. Pigments in small-size fractions as a proportion of pigments in whole samples, and maximum observed concentrations

\begin{tabular}{|ccccc|}
\hline $\begin{array}{c}\text { Size fraction } \\
(\mu \mathrm{m})\end{array}$ & \multicolumn{2}{c}{$\begin{array}{c}\text { Chlorophyll } a \\
\text { \% Total }\end{array}$} & $\begin{array}{c}\text { Chlorophyl } c \\
\text { (mg m }\end{array}$ \\
\hline$<5.0$ & $\leq 4$ & 32 & $\leq 20$ & $\begin{array}{c}\text { Total } \\
\text { Max. } \\
\left(\mathrm{mg} \mathrm{m}^{-3}\right)\end{array}$ \\
\hline 1.0 & $\leq 3$ & 13 & $\leq 10$ & 9 \\
\hline
\end{tabular}

the chlorophyll biomass. Values in Table 1 indicate that these small proportions did not reflect low concentrations of picoalgae at the ice-water interface, but rather very high concentrations of the larger species. Pennate diatoms belonging to the genera Nitzschia and Navicula dominated the large cells (67 to $93 \%$ ), with $\approx 50 \%$ of Nitzschia frigida (Barlow in press). The fact that ice picoalgae were richer than large diatoms in chlorophyll $c$ relative to chlorophyll a suggests that these small cells were eucaryotes rather than cyanobacteria, since the latter have no chlorophyll $c$. It was not possible to identify the small algae directly in the field, for lack of an epifluorescence microscope at the sampling site (Hobbie et al. 1977. Glover et al. 1985).

Table 2 lists photosynthetic efficiencies for the various size fractions, normalized per unit chlorophyll $a$
Table 2. Photosynthetic efficiency $\left(\alpha^{\mathrm{B}} ; \mathrm{mgC} \mathrm{mg} \mathrm{pigment}{ }^{-1} \mathrm{~h}^{-1}\right.$ $\mu$ Einst ${ }^{-1} \mathrm{~m}^{2} \mathrm{~s}$ ) in the various size fractions, normalized per unit chlorophyll $a$ and per unit chlorophylls $a+c$

\begin{tabular}{|ccc|}
\hline $\begin{array}{c}\text { Size fraction } \\
(\mu \mathrm{m})\end{array}$ & \multicolumn{2}{c|}{ Normalizing pigments (B) } \\
Chlorophyll $a$ & Chlorophylls $a+c$ \\
\hline$>5.0$ & $0.013-0.023$ & $0.011-0.020$ \\
$>1.0$ & $0.012-0.022$ & $0.011-0.018$ \\
$<5.0$ & NS & NS \\
$<1.0$ & $\approx 0.007$ & $0.004-0.007$
\end{tabular}

NS: $\alpha^{B}$ not significantly different from zero (prob. $\geq 0.05$ )

and per unit chlorophylls $a+c$. Efficiencies significantly different from zero in the $<1 \mu \mathrm{m}$ fraction provide additional evidence that the observed small chlorophyll-containing particles were indeed algal cells. Photosynthetic efficiency of the $<1 \mu \mathrm{m}$ fraction was lower than that of large diatoms, which are known to be well adapted to the very low light intensities of the ice environment (e.g. Gosselin et al. 1985, Rochet et al. 1986, Barlow et al. in press). During most of the sampling season, the under-ice photon fluence rate was below $50 \mu$ Einst $\mathrm{m}^{-2} \mathrm{~s}^{-1}$ (Barlow et al. in press). It appears that cells $<1 \mu \mathrm{m}$ were not as well adapted as large ice diatoms to these low fluence rates, which is contrary to what has generally been observed in open waters for picoplankton (see above). 
The occurrence of very small photosynthetic cells in the sea ice calls for taxonomic studies on this component of the microflora. This had already been stressed by Horner (1985b). In addition, the photosynthetic characteristics of the $<1 \mu \mathrm{m}$ fraction seem to be different from those of the large ice diatoms, and in a way which is reverse to that reported for oceanic waters. Research on this aspect could lead to useful physioecological comparisons. Finally, even if the biomass and photosynthetic efficiency of the smaller photosynthetic organisms are low by comparison to those of the large cells, protozoans in the sea ice (see Carey 1985, for the Arctic, and Lipps \& Krebs 1974, for the Antarctic) are potential grazers for the $<1 \mu \mathrm{m}$ algal cells. In open waters, it has been proposed (e.g. Goldman 1984, Gray et al. 1984) that picoplankton production can support a 'microbial loop' in the food web. The existence of picoalgae and potential grazers suggests that a similar microbial loop may play a role in the seaice environment.

Acknowledgements. This research was supported by the Natural Sciences and Engineering Research Council of Canada (strategic and individual research grants to L. L.), by the Maurice-Lamontagne Institute (Department of Fisheries and Oceans), and by grants to GIROQ from the Fonds FCAR of Québec and NSERC. Helicopter time was provided by Fisheries and Oceans. Housing was at the Kuujjuarapik field station of the Centre d'études nordiques, Université Laval, where we benifited from the invaluable assistance of the superintendent C. Côté. We thank D. Allan, M. Dubé, A. Gagné, P. Jalbert, P. Joly and K. Walker for their assistance in the field and in the laboratory.

\section{LITERATURE CITED}

Barlow, R. G., Alberte, R. S. (1985). Photosynthetic characteristics of phycoerythrin-containing marine Synechococcus spp. I. Responses to growth photon flux density, Mar. Biol. 86: $63-74$

Barlow, R. G., Gosselin, M., Legendre, L., Therriault, J. C., Demers, S., Llewellyn, C. A., Mantoura, R. F. C. (in press). Photoadaptive strategies in sea-ice microalgae. Mar. Ecol. Prog. Ser.

Berman, T (1975). Size fractionation of natural aquatic populations associated with autotrophic and heterotrophic carbon uptake. Mar. Biol. 33: 215-220

Carey, A. G. (1985). Marine ice fauna: Arctic In: Horner, R. A. (ed.) Sea ice biota. CRC Press, Boca Raton, p. 173-190

Carr, N. G., Wyman, M. (1986). Cyanobacteria: their biology in relation to oceanic picoplankton. In: Platt, $\mathrm{T}$. $\mathrm{Li}$, W. K.W (ed) Photosynthetic picoplankton. Can. Bull. Fish. Aquat. Sci. 214: 159-204

Demers, S., Legendre, L., Therriault, J C., Ingram, R. G. (1986). Biological production at the ice-water ergocline. In: Nihoul, J. C. J. (ed.) Marine interfaces ecohydrodynamics Elsevier, Amsterdam, p. 31-54

Doty, M. S., Oguri, M. (1959). The carbon-fourteen technique for determining primary plankton production. Pubbl. Staz. zool. Napoli 31 (Suppl.): 70-94
Glover, H. E., Campbell, L., Prézelin, B. B. (1986a). Contribution of Synechococcus spp. to size-fractionated primary productivity in three water masses in the Northwest Atlantic Ocean. Mar. Biol. 91: 193-203

Glover, H. E., Keller, M. D., Guillard, R. R. L. (1986b). Light quality and oceanic ultraphytoplankters. Nature, Lond. 319: $142-143$

Glover, H. E., Morris, I. (1981). Photosynthetic characteristics of coccoid marine cyanobacteria. Arch. Microbiol. 129: $42-46$

Glover, H. E., Phinney, D. A., Yentsch, C. S. (1985). Photosynthetic characteristics of picoplankton compared with those of larger phytoplankton populations, in various water masses in the Gulf of Maine. Biol. Oceanogr 3: 223-248

Goldman, J. (1984). Oceanic nutrient cycles. In: Fasham, M. J. R. (ed.) Flows of energy and materials in marine ecosystems: theory and practice. Plenum Press, New York, p. $137-170$

Gosselin, M., Legendre, L., Demers, S., Ingram, R. G. (1985). Responses of sea-ice microalgae to climatic and fortnightly tidal energy inputs (Manitounuk Sound, Hudson Bay). Can. J. Fish. Aquat. Sci, 42: 999-1006

Gray, J. S., Field, J. G., Azam, F., Fenchel, T., Meyer-Reil, L. A., Thingstad, F. (1984). The role of free bacteria and bactivory. In: Fasham, M. J. R. (ed.) Flows of energy and materials in marine ecosystems: theory and practice. Plenum Press, New York, p. 707-723

Herbland, A., Le Bouteiller, A. (1981). The size distribution of phytoplankton and particulate organic matter in the Equatorial Atlantic Ocean: importance of ultraseston and consequences. J. Plankton Res. 3: 659-673

Hobbie, J. E., Daley, R. J., Jasper, S. (1977). Use of Nuclepore filters for counting bacteria by fluorescence microscopy. Appl. environ. Microbiol. 33: 1225-1228

Horner, R. A. (1985a). Ecology of sea ice microalgae. In: Horner, R. A. (ed.) Sea ice biota. CRC Press, Boca Raton, p. $83-103$

Horner, R. A. (1985b). Taxonomy of sea ice microalgae. In: Horner, R. A. (ed.) Sea ice biota. CRC Press, Boca Raton, p. 14.7-157

Jeffrey, S. W., Humphrey, G. F. (1975). New spectrophotometric equations for determining chlorophylls $a, b, c_{1}$ and $c_{2}$ in higher plants, algae, and natural phytoplankton. Biochem. Physiol. Pflanz. 167: 191-194

Joint, I. R., Owens, N. J. P., Pomroy, A. J. (1986). The seasonal production of photosynthetic picoplankton and nanoplankton in the Celtic Sea. Mar. Ecol. Prog. Ser. 28: 251-258

Joint, I. R., Pomroy, A. J. (1983). Production of picoplankton and small nanoplankton in the Celtic Sea. Mar. Biol. 77 : $19-27$

Joint, I. R., Pomroy, A. J. (1986). Photosynthetic charactenstics of nanoplankton and picoplankton from the surface mixed layer. Mar. Biol. 92: 465-474

Lean, D. R. S., Burnison, B. K. (1979). An evaluation of errors in the ${ }^{14} \mathrm{C}$ method of primary production measurement. Limnol. Oceanogr. 24: 917-928

Li, W. K. W. (1986). Experimental approaches to field measurements: methods and interpretation. In: Platt, I., Li, W. K. W. (ed.) Photosynthetic picoplankton. Can. Bull. Fish. Aquat. Sci. 214: 251-286

Li, W. K. W., Subba Rao, D. V., Harrison, W. G., Smith, J. C. Cullen, J. J., Irwin, B., Platt, T (1983). Autotrophic picoplankton in the tropical ocean. Science 219: 292-295

Lipps, J. H., Krebs, W. N. (1974). Planktonic foraminifera associated with Antarctic sea-ice. J. foram. Res. 4: 80-85

Mantoura, R. F. C., Llewellyn, C. A. (1983). The rapid determi- 
nation of algal chlorophyll and carotenoid pigments and their breakdown products in natural waters by reversephase high-performance liquid chromatography. Analytica chim. Acta 151: 297-314

Morris, I., Glover, H. E. (1981). Physiology of photosynthesis by marine coccoid cyanobacteria - some ecological implications. Limnol. Oceanogr. 26: 957-961

Murphy, L. S., Haugen, E. M. (1985). The distribution and abundance of phototrophic ultraplankton in the North Atlantic. Limnol. Oceanogr. 30: 47-58

Paerl, H. W. (1977). Nanoplankton vs netplankton photosynthetic and heterotrophic activities in Fijian waters of the South Pacific Ocean. Lau-Tonga Bull. 117: 211-221

Platt, T., Subba Rao, D. V., Irwin, B. (1983). Photosynthesis of picoplankton in the oligotrophic ocean. Nature, Lond. 301 : $702-704$

Prézelin, B. B., Putt, M., Glover, H. E. (1986). Diurnal patterns in photosynthetic capacity and depth-dependent photosynthesis-irradiance relationships in Synechococcus spp. and larger phytoplankton in three water masses in the Northwest Atlantic Ocean. Mar. Biol. 91: 205-217

Probyn, T A., Painting, S. J. (1985). Nitrogen uptake by sizefractionated phytoplankton populations in Antarctic surface waters. Limnol. Oceanogr. 30: 1327-1332

Pugh, P. R. (1973). An evaluation of liquid scintillation counting techniques for use in aquatic primary production studies. Limnol. Oceanogr. 18: 310-319

Putt, M. Prézelin, B. B. (1985). Observations of diel patterns of photosynthesis in cyanobacteria and nannoplankton in the Santa Barbara Channel during el Niño. J. Plankton Res. 7 : $779-790$

Rochet, M., Legendre, L., Demers, S. (1986). Photosynthetic and pigment responses of sea-ice microalgae to changes in light intensity and quality. J. exp. mar. Biol. Ecol. 101: 211-226
Sieburth, J. McN., Smetacek, V., Lenz, J. (1978). Pelagic ecosystem structure: heterotrophic compartments of the plankton and their relationship to plankton size fractions. Limnol. Oceanogr 23: 1256-1263

Strickland, J. D. H., Parsons, T R. (1972). A practical handbook of seawater analysis, 2nd edn. Bull. Fish. Res. Bd. Can. 167: 1-310

Subba Rao, D. V., Platt, T. (1984). Primary production of Arctic waters. Polar. Biol. 3: 191-201

Sullivan, C. W. (1985). Sea ice bacteria: reciprocal interactions of the organisms and their environment. In: Horner, R. A. (ed.) Sea ice biota. CRC Press, Boca Raton, p. $159-171$

Sverdrup, H. U., Johnson, M. W., Fleming, R. H. (1942). The oceans. Prentice-Hall, Englewood Cliffs

Takahashi, M., Bienfang, P. K. (1983). Size structure of phytoplankton biomass and photosynthesis in subtropical Hawaiian waters. Mar. Biol. 76: 203-211

Takahashi, M., Hori, T. (1984). Abundance of picoplankton in the subsurface chlorophyll maximum layer in subtropical and tropical waters. Mar. Biol. 79: 177-186

Takahashi, M., Kikuchi, K., Hara, Y. (1985). Importance of picocyanobacteria biomass (unicellular, blue-green algae) in the phytoplankton population of the coastal waters off Japan. Mar. Biol. 89: 63-69

Thomsen, H. A. (1986). A survey of the smallest eucaryotic organisms of the marine phytoplankton. In: Platt, $\mathrm{T}$., Li, W. K. W. (ed.) Photosynthetic picoplankton. Can. Bull. Fish. Aquat. Sci. 214: 121-158

Waterbury, J. B., Watson, S. W., Valois, F. W., Franks, D. G. (1986). Biological and ecological characteristization of the marine unicellular cyanobacterium Synechococcus. In: Platt, T., Li, W. K. W. (ed.) Photosynthetic picoplankton. Can. Bull. Fish. Aquat. Sci. 214: 71-120

This note was submitted to the editor; it was accepted for printing on July 17, 1987 